\title{
Raising Students' Motivation and Learning Interest Through Discipline: SMP Negeri 1 Barru Context
}

\author{
Abdul Kahar Yunus ${ }^{1} \&$ Nurafiyat Ekamurti ${ }^{2}$ \\ ${ }^{1}$ STKIP Muhammadiyah Barru. Barru. Indonesia \\ ${ }^{2}$ STKIP Dampal Selatan. Toli-Toli. Indonesia \\ nurafiyatamir@gmail.com
}

\section{ARTICLE HISTORY}

Received

Revised

Accepted

\section{KEYWORDS}

Discipline

Motivation

Learning Interest

\begin{abstract}
This study aims to examine how the application of discipline to improve students' motivation and learning interest at SMP Negeri 1 Barru. The sample in this quantitative study was taken through proportional random sampling. Based on the results of the study, it can be concluded that there is a significant influence of the application of discipline to the increase of students' motivation and learning interest at SMP Negeri 1 Barru. This can be seen in the significance value of the value of $t_{\text {count }}$ and $t_{\text {table }}$ namely $t_{\text {count }}(3.5)$ is higher than $t_{\text {table }}$ (1.99). The strength of the influence of the application of discipline to students' motivation and interest in learning at SMP Negeri 1 Barru reached 0.4 level, which means it is in a good category.
\end{abstract}

\section{Introduction}

Learning for students is an inevitable obligation. Learning for students is for a lifetime, because learning has never known young and old, rich and poor. For a student there should be no word of stop learning. This is in line with the opinions expressed by (Bruner, 1977) that students should continue school education to the highest level, and achieve their dream goals.

In fact in Indonesia there are still many schoolaged children who do not continue school for various reasons (Asrori, 2007). There are even children who have not been touched at all by education. Therefore, the Indonesian government formulated an educational program that is school age being 9 years compulsory education, so that every child has the right to attend school until the age of 9 years, or until junior high school $(S M P)$. In addition, the Indonesia government has prepared a free education program and the disbursement of education funds up to $20 \%$ of the national budget (Depdiknas, 2008). This is certainly encouraging, although in reality, drop-out-of-school children or-quit school children are also still available in Indonesia.

School as a place of learning for students has its own rules that must be obeyed. According to the results of research conducted by (Nashruddin, Ningtyas, and Ekamurti, 2018) it is known that, for students who want to learn well, following the rules is an obligation that cannot be tolerated. Obeying rules means applying discipline. The application of discipline in schools does have many variants. Being a disciplined person is everyone's dream. Discipline includes discipline of time, discipline of action, discipline in learning. All of these are good things that must be applied in this life.

Discipline in following the rules set by the school, can help students to become excellent students. Students who are disciplined can set themselves to be independent, without being asked not to commit violations at school. Students who are disciplined will always prepare themselves to learn (Noddings, 1995).

In fact, students who often break the rules at school are often found at SMP Negeri 1 Barru. This is related to the lack of motivation and interest in learning. Students who have problems, for example skipping lessons, may be caused by a lack of motivation and interest to learn. Therefore, the application of discipline can foster motivation and interest in student learning. Based on the background above, the research problem formulation is "How is the effect of the application of discipline on student motivation and learning interest in SMP Negeri 1 Barru?"

\section{Review of Literature}

(Soejono, 2003) stated that in daily conversation discipline is usually associated with an orderly situation. In other words, discipline is a condition in which a person's behavior follows certain predetermined patterns. Discipline means being able to do what has been agreed to, whether written, oral, or in the form of regulations or customs.

Discipline can also be interpreted as the attitude of a person or group who intends to follow the rules that have been set. According to (Sudarsono, 2012) discipline aims to shape humans to achieve goals that are further from what humans might reasonably 
achieve in life. A research conducted by (Whitford, Katsiyannis, and Counts, 2016) indicated that without discipline, it is impossible for someone who claims to be a religion to disobey and submit to his religion. In short, discipline is a person's ability to obey and obey a rule of law.

According to Woolfolk (2001) motivation is a change of energy in a person (person) that is marked by the emergence of feelings and reactions to achieve goals. The root word of motivation is motive. Motive shows an impulse arising from within a person that causes the person to want to act to do something. Whereas motivation is the driving force of a conscious effort to influence a person's behavior so that he is moved to act to do something so as to achieve certain results or goals.

From the results of research conducted by (Nashruddin et al., 2018) it is also known that motivation is the overall driving force within students that lead to learning activities, which ensures continuity of learning activities and gives direction to learning activities, so that the desired goals of students are achieved. In the study, they confirmed that there are three elements related to the formulation of motivation, namely:

a) Motivation starts from a change in energy in the person. Changes in motivation arise from certain changes in the neuropathic system in human organisms.

b) Motivation is characterized by feelings of affective arousal. First it is psychological tension, then it is emotional atmosphere. This atmosphere of emotion creates patterned behavior.

c) Motivation is characterized by reactions to achieve goals. Motivated individuals hold responses aimed at one goal. These responses function to reduce the tension caused by changes in energy towards achieving the goal.

For all people, learning is an obligation. Therefore, success or failure of a person in education depends on the learning process experienced by him/ her (BardoviHarlig, Mossman, \& Vellenga, 2014). In everyday life humans do many activities that are actually "symptoms of learning", in the sense that it is impossible to do those activities, without learning first. Examples of learning are wearing clothes, eating with cutlery, communicating with each other in national languages and so on .

Learning is not only done at school, but can be done everywhere, such as at home or in the community. Bruner, 1977) stated that Learning is a process of change from being unable to being able and occurring within a certain period of time. Learning is a business or activity that aims to make changes in a person, including changes in behavior, attitudes, habits, knowledge, skills and so on.
In learning, students experience the process from not knowing to knowing. Thus, learning can be said to be successful if there is a change in students. However, not all changes in behavior can be said to be learning because changes in behavior due to learning have distinctive manifestation characteristics (Syah, 2014).

Interest is the tendency of the heart to something high, passion, desire (Chaplin, 2009). Meanwhile according to (Johnson, Jabbari, Williams, and Marcucci, 2019) definitions of learning are (1) trying to gain intelligence or knowledge; (2) practicing. Menurut pengertian ini belajar merupakan suatu proses, suatu kegiatan dan bukan suatu hasil atau tujuan. Based on this explanation, learning is a process, an activity and not an outcome or objective. Learning is not just remembering but it is broader than that, namely experiencing. Learning outcomes are not a mastery of the results of the exercise but a change of behavior.

Research shows that the evidence that someone has learned is a change in behavior in that person, for example from not knowing to knowing and from not understanding to understanding. If someone has done the act of learning, it will be seen a change in one or several aspects of the behavior (Lee, 2015).

According to (Sumiati, 2008) some learning principles are as follows:

1) The learning process is experience, doing, reacting and transcending

2) The process is through a variety of experiences and subjects that are focused on a particular goal.

3) The maximum learning experience is meaningful for student life.

4) The learning experience comes from the students' own needs and goals which encourage continuous motivation.

5) The learning process and learning outcomes are demanded by heresy and the environment.

6) The learning process and the results of learning efforts are materially influenced by individual differences among students.

7) The learning process takes place effectively if the experiences and desired results are adjusted to the student's maturity.

8) The best learning process if students know the status and progress.

9) The learning process is a functional unity of various procedures.

10) Learning outcomes are functionally related to one another, but can be adjusted separately. 
11) The learning process takes place effectively under the guidance that stimulates and guides without pressure and coercion.

12) Learning outcomes are patterns of behavior, values, understanding, attitudes, appreciation, ability and skills.

13) Learning outcomes are accepted by students when they are satisfied with their needs and are useful and meaningful to them.

14) Learning outcomes are complemented by a series of experiences that can be compared and with good judgment.

15) Learning outcomes that have been achieved are complex and changeable, not simple and static.

Based on the opinion above, it is understood that the notion of interest in learning is the tendency of individuals to have a sense of pleasure, encouragement to carry out activities towards learning activities carried out through exercises or experience. With the interest in learning in students, learning activities will be carried out with awareness. Learning activities will be fun and accompanied by encouragement to obtain optimal learning results.

\section{Method}

The location of this research is SMP Negeri 1 Barru, on Sultan Hasanuddin Street, Barru Regency. Determination of the sample in this study was taken as a proportional random sampling. Random sampling is a technique of randomizing or drawing respondents to be selected as research samples so that the possibility of special treatment of respondents is slim.

To determine the size of the sample taken from the population, the researchers rely on the determination put forward by (Arikunto, 2002) that if the research subjects are more than 100 people, samples can be drawn between $10 \%$ and $25 \%$ or more. By paying attention to the large population and time constraints, the researchers took $10 \%$ of the total population of 664 students. Therefore, $664 \times 10 \%=66$ students are taken as respondents.

Types of research data are primary data and secondary data. Primary data is the main data. In this data collection questionnaire is used by giving a number of questionnaires to all respondents. A number of those questions are used to obtain information from the respondent in the sense of a report about his personality, or things he wants to know. Secondary data is supporting data. This type of data was collected from some of the result of previous research, and from literature studies by reading books related to this research. Data sources of this study are the principal, guardian teacher, and students of VII class, dan VIII class at SMP Negeri 1 Barru.
Data analysis used was data analysis to determine the effect of the application of discipline on student motivation and interest in learning. Thus the $X$ variable is the application of discipline, and the $\mathrm{Y}$ variable is motivation and interest in learning. Both of these variables are analyzed by the correlation formula of product moment as follows:

$$
\operatorname{rxy}=\frac{n\left(\sum X Y\right)-\left(\sum X\right)\left(\sum Y\right)}{\sqrt{\left(n \sum X^{2}-\left(\sum X\right)^{2}\right)\left(n \sum Y^{2}-\left(\sum Y\right)^{2}\right)}}
$$

Information:

$\mathrm{X}=$ Score of $\mathrm{X}$ Variable

$\mathrm{Y}=$ Score of $\mathrm{X}$ Variable

$\mathrm{N}=$ Number of respondent

$\mathrm{r}_{\mathrm{XY}}=$ The correlation coefficient between $\mathrm{X}$ and $\mathrm{Y}$

To find out the magnitude of the relationship or influence between the two variables, then value "r" interpreted as follows:

1) $0,800-1,000$ (the effect of $\mathrm{X}$ on $\mathrm{Y}$ is very strong)

2) $0,600-0,800$ (the effect of $x$ on $y$ is strong)

3) $0,400-0,600$ (the effect of $x$ on $y$ is strong enough)

4) 0,200-0,399 (the effect of $x$ on $y$ is weak)

5) $0,000-0,200$ (the effect of $x$ on $y$ is very weak)

\section{Findings and Discussion}

After the $X$ variable was determined namely student discipline, and the $\mathrm{Y}$ variable was student motivation and learning interest, the questionnaire was distributed with certain indicators. Furthermore, the formula is outlined in the form of a research questionnaire in accordance with the two variables in this study.

Hypothesis testing was done by finding the amount of significance between $t_{\text {table }}$ and $t_{\text {count }}$. The hypothesis of this study is that there is an influence of the application of discipline to the motivation and learning interest of students at SMP Negeri 1 Barru. Thus, the hypothesis can be made in the following format:

$\mathrm{Ha}=$ There is an influence on the application of discipline to students' motivation and interest in learning at SMP Negeri 1 Barru

$\mathrm{Ho}=$ There is not an influence on the application of discipline to students' motivation and interest in learning at SMP Negeri 1 Barru

The principle of hypothesis testing is: 
while

If $\mathrm{t}_{\text {count }} \leq \mathrm{t}_{\text {table }}$ then accept Ho, means not significant

Based on the above calculation with $\alpha=0.05$ and $\mathrm{n}=66$ then $\mathrm{dk}=\mathrm{n}-2=66-2=64$, so obtained that $\mathrm{t}_{\text {table }}=1,988$. Based on the distribution of t-value, it was found that $\mathrm{t}_{\text {count }}$ was bigger than $\mathrm{t}_{\text {tabel }}$, or $3.5>$ 1.988 , then it can be mentioned that Ho was rejected. That means there is a significant influence between the application of discipline to students' motivation and learning interest in SMP Negeri 1 Barru.

\section{Conclusion}

Based on observation, data collection, and data analysis, it can be concluded that there is a significant influence of the application of discipline to the motivation and learning interest of students at SMP Negeri 1 Barru. This is seen in the significance of the value of $t_{\text {count }}$ and $t_{\text {table, namely }} t_{\text {count }}$ is higher than $t_{\text {table, }}$ or $3.5>1.988$. The strength of the influence of discipline on students' motivation and interest in learning at SMP Negeri 1 Barru reaches 0.4, which means that the influence is in the strong enough category.

\section{References}

Arikunto, S. (2002). Prosedur Penelitian suatu Pendekatan Praktik. Jakarta: Rineka Cipta.

Asrori, M. (2007). Psikologi Pembelajaran. Bandung: Wacana Prima.

Bardovi-Harlig, K., Mossman, S., \& Vellenga, H. E. (2014). The effect of instruction on pragmatic routines in academic discussion. Language Teaching Research, 19(3), 324-350. doi: 10.1177/1362168814541739

Bruner, J. S. (1977). The Process of Education. Cambridge: Harvard University Press.

Chaplin, J. P. (2009). Kamus Lengkap Psikologi. Jakarta: Raja Grafindo Persada.

Depdiknas. (2008). Kamus Besar Bahasa Indonesia. Jakarta: Gramedia.

Gagne, R. M. (2008). Prinsip-prinsip Belajar Untuk Pengajaran di Sekolah. Surabaya: Usaha Nasional.

Johnson, O., Jabbari, J., Williams, M., \& Marcucci, O. (2019). Disparate Impacts: Balancing the Need for Safe Schools With Racial Equity in Discipline. Policy Insights from the Behavioral and Brain Sciences, 6(2), 162-169.

Lee, B. (2015). EFL Learners' Perspectives on ELT Materials Evaluation Relative to Learning Styles. RELC Journal, 46(2), 147-163.
Nashruddin, N., Ningtyas, P. R., \& Ekamurti, N. (2018). Increasing The Students'motivation In Reading English Materials Through Task-Based Learning (Tbl) Strategy (A Classroom Action Research at the First Year Students of SMP Dirgantara Makassar). Scolae: Journal of Pedagogy, 1(1), 44-53.

Noddings, N. (1995). Philosophy of Education. Colorado: Westview Press, Inc.

Soejono, S. (2003). Sosiologi Suatu Pengantar. Jakarta: Rajawali.

Sudarsono. (2012). Kenakalan Remaja. Jakarta: Rineka Cipta.

Sumiati. (2008). Metode Pembelajaran. Bandung: Wacana Prima.

Syah. (2014). Langkah-langkah Operasional Model Pembelajaran Discovery. from http://www.ekaikhsanudin.net/2014/12/pembelaja ran-model-discoverylearning.html\#ixzz4PQ8LStT9

Whitford, D. K., Katsiyannis, A., \& Counts, J. (2016). Discriminatory Discipline: Trends and Issues. NASSP Bulletin, 100(2), 117-135.

Woolfolk, A. (2001). Educational Psychology (8th ed.). United States: A Pearson Education Company. 